\title{
The Effect of Two Exercise Types in the 8 Week Exercise Training on the Physical Fitness of Elderly Women
}

\author{
Inhwa Yoo', Hyung-Min Yoon ${ }^{1 *}$ \\ 'Dankook University, Chungcheongnam-do, Republic of Korea
}

\author{
Received: October 2, 2019 \\ Accepted: January 17, 2020 \\ Published online: January 31, 2020 \\ Keywords: \\ Elastic Band Exercise \\ Gyrokinesis Exercise \\ Physical Fitness \\ Specificity of Exercise
}

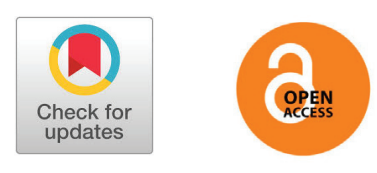

\section{ABSTRACT}

OBJECTIVES The purpose of this study was to investigate the effect of two exercise types (Gyrokinesis exercise and Elastic band exercise) in the 8 week exercise training on the physical fitness of elderly women.

METHODS The subjects of this study were 57 elderly women between 65 and 80 years old, who had no abnormality in the Physical Readiness Questionnaire (PAR-Q test) and were able to do physical activity on the orthopedic standpoints. The subjects were divided into three groups: Gyrokinesis Exercise Group (GKEG: $n=19$ ), Elastic Band Exercise Group (EBEG: $n=20$ ), and Control Group (CG: $n=18$ ). The subjects performed a Gyrokinesis Exercise in GKEG and an Elastic Band Exercise in EBEG for 50 minutes a day (10 minutes for warm-up, 30 minutes for main exercise, 10 minutes for cool-down), and 3 times a week for a total of 8 weeks. The subjects of CG did not participate in any particular exercise program but only everyday life. The dependent variables were Physical Fitness: Upper Muscular Endurance, 30-Second Arm Curl. Lower Flexibility, Dynamic Balance, Endurance. one-way ANOVA with repeated measurements was used to test the hypothesis in this study. A post hoc was conducted only when there was an interaction effect between groups and measurements. The difference of the post-test between groups were analyzed through Scheffe method after one-way ANOVA. The statistical significance level of this study was $\alpha=.05$.

RESULTS Gyrokinesis and Elastic Band Exercises were both effective on the physical fitness of elderly women: Upper Muscular Endurance, 30-Second Arm Curl, Lower Flexibility, Dynamic Balance, and Endurance. However, there were no differences in exercise effects after 8 week exercise training between the Gyrokinesis Exercise Group and the Elastic Band Exercise Group.

CONCLUSIONS It is concluded that Gyrokinesis and Elastic Band exercise programs should be encouraged to improve physical fitness of elderly women and we need a follow-up study with longer term exercise training programs to find the differences in exercise effects between Gyrokinesis Exercise and Elastic Band Exercise.

๑ The Asian Society of Kinesiology and the Korean Academy of Kinesiology

\section{서론}

인간의 평균 수명이 증가함[1]에 따라 “건강하게 늙 고 편안한 죽음(Healthy Ageing and Well-Dying)에 이르고자 하는 열망”이 강해지면서 운동을 통한 노년의 체력관리에 대한 관심이 높아지고 있다.

*Correspondence: Hyung-Min Yoon, Dankook University, 119, Dongnam-gu, Cheonan-si, Chungcheongnam-do, Republic of Korea; Tel: +82-10-4191-2046; E-mail: hyungmin1026@hanmail.net
그러나 실제로 운동을 하는 노인들의 비율은 그리 높 지 않다는데 문제가 있다. 한국건강증진개발원 [2]에 의 하면, 70 세 이상 노인의 신체활동 실천율은 $29.8 \%$ 로서 $66.7 \%$ 인 20 대의 절반수준에 머무르고 있다. 더욱이 여 성노인의 경우 평균수명은 남성노인보다 길지만[1], 신 체활동 참여율(27.9\%)이 남성노인(41.7\%) 보다 현저히 낮은 [2] 관계로 여성 노인들의 운동관리가 더욱 절실한 실정이다. 특히, 신체활동 부족은 노인들의 신체를 더 욱 허약하게 만들어 신체활동을 온전히 수행할 수 없게 
만들 뿐만 아니라[3] 근감소증[4,5], 낙상[6,7], 치매 $[8,9]$ 등의 질환 등으로 고통을 수반한 삶을 살게 하는 요 인이 되므로 다양한 노인 운동프로그램을 제공함으로써 노인들이 신체활동을 증진시킬 수 있도록 하는 것이 무엇 보다 중요하다.

Paterson 등[10] 및 U. S. Department of Health and Human Services[11]는 노년기의 신체활동은 근력, 근지구력과 같은 기초체력 뿐만 아니라 보행이나 계단 오 르기 등의 기능도 개선시킬 수 있다고 하였고, 미국스포 츠의학회[3]는 노인의 운동프로그램은 운동 강도가 낮 고, 손상의 위험성이 적은 단순한 도구를 사용하는 운동 을 권장하고 있다.

최근 자이로토닉 익스팬션 시스템(Gyrotonic Expansion System)이 개발되면서 이 운동이 노인운동 으로서 적합한가에 대한 관심이 높아지고 있다. 이 운동 은 본래 척추 기능 향상을 위해 개발된 운동으로 요통완 화[12] 및 척추건강[13], 보행 패턴[14] 등에 관한 연구 가 주류를 이루고 있지만 아직까지 연구 사례가 많지 않 고, 피험자의 연령도 20 대 위주로 연구되어 있다.

자이로토닉 익스펜션 시스템은 기구 운동인 자이로토 닉(Gyrotonic) 운동과 맨손체조 형태의 자이로키네시스 (Gyrokinesis) 운동으로 나뉘어져 있다. 그 중에서 자이 로키네시스 운동은 특별한 기구 없이 좁은 공간에서 편리 하게 할 수 있는 맨손 운동으로서 노인들의 체력관리에 널리 활용될 수 있는 장점이 있다. 자이로키네시스 운동 은 신체의 대근육군을 수동적으로 늘려주는(passive way of stretching) 전통적인 요가와는 달리, 국소근육 들과 대근육들이 원활하게 움직이게 하는 능동적 늘림 (active way of stretching)에 기반을 두고 '7가지 방향 의 척추 움직임’에 기본 원리를 두고 있다. 다양한 호흡을 수반한 원형 및 곡선 동작으로 구성된[15] 좌우대칭의 리드미컬 한 유산소성 형태의 운동으로서 운동의 동작이 완만하고 부드러우며 운동범위의 개별화가 용이하여 노 인들도 쉽게 참여할 수 있는 장점이 있다. 그러나 자이로 키네시스 운동이 노인들에게 어떤 효과가 있는지에 대한 연구가 발견되지 않고 있다.

한편, 탄성 밴드 운동은 근육 강화[16] 및 신경계 기 능 강화를 통한 운동손상의 예방 및 재활[17]을 위한 운 동으로 널리 사용되어 왔다. 이 운동은 부드럽고 탄력적 인 고무줄이나 밴드를 사용함으로써 상대적으로 손상의 위험이 적고, 운동 강도의 조절이 용이하며[18], 운동 범 위에서 근육을 최대한 활성화 시키고 다양한 각도
로 동작을 실시하면서도 충격을 최소화 할 수 있다[19]. 아울러 탄성 밴드는 비용이 저렴하고 무게가 가벼워 운 반이 쉬우며 좁은 공간에서 운동이 가능한 동시에 여러 관절의 운동에서 적절하게 사용할 수 있는 소도구로서 노인들을 대상으로 근력증진[20]이나 치매[21], 근감 소증[22] 관련 연구에서 많이 활용되고 있다.

이와 같이 자이로키네시스 운동이나 탄성 밴드 운동 은 노인들이 좁은 공간에서 단순한 도구를 사용하고 쉽 게 운동을 할 수 있으며 편리한 운동이라는 측면에서 그 효과를 비교해 볼 가치가 있다. 따라서 이 연구는 8주간 진행된 자이로키네시스 운동 훈련과 탄성 밴드 운동 훈 련이 여성 노인의 기초체력에 미치는 영향을 규명함과 동시에, 두 가지 운동 형태에 따른 기초체력의 변화의 차 이가 8 주 이내에 일어날 수 있는가를 살펴보고자 한다.

\section{연구방법}

\section{연구대상}

이 연구의 대상자는 서울 $\mathrm{G}$ 지역 노인정에서 임의 표집 된 노인 여성(65-80세) 57명이었다. 이 연구의 대상자 규모는 $\mathrm{G}$-power 3.1.9.2를 통하여 결정되었 다. 이들은 정형외과학적으로 운동이 가능한 사람들 로 판정받았으며 신체활동 준비상태 설문지(ACSM's Physical Readiness Questionnaire; PAR-Q) 검사에 서 이상이 없었고 이 연구의 실험이 시작되기 6 개월 이전까지 규칙적인 운동 프로그램에 참가한 경험이 없 는 사람들이었다. 이들은 사전 검사와 실험처치에 대 한 설명을 듣고 이해하였으며 이 연구에 자발적으로 동 의서에 서명 후 자이로키네시스 운동군(Gyrokinesis Exercise Group, GKEG: n=19), 탄성 밴드 운동군 (Elastic Band Exercise Group, EBEG: n=20), 통제

\begin{tabular}{|c|c|c|c|c|c|}
\hline Group & $\begin{array}{c}\text { GKEG } \\
(n=19)\end{array}$ & $\begin{array}{c}\text { EBEG } \\
(n=20)\end{array}$ & $\begin{array}{c}\text { CG } \\
(n=18)\end{array}$ & $\begin{array}{c}\text { Levene's } \\
\boldsymbol{F}\end{array}$ & $\mathbf{p}$ \\
\hline Age (yrs) & $78.00 \pm 8.26$ & $79.60 \pm 3.71$ & $77.61 \pm 6.73$ & 7.965 & .061 \\
\hline Weight (kg) & $58.58 \pm 6.44$ & $59.83 \pm 10.92$ & $58.80 \pm 10.87$ & 3.683 & .072 \\
\hline Height (cm) & $147.57 \pm 4.58$ & $149.16 \pm 6.13$ & $148.67 \pm 3.90$ & 2.494 & .092 \\
\hline $\begin{array}{l}\text { HRrest } \\
\text { (beats/min) }\end{array}$ & $72.26 \pm 11.42$ & $74.75 \pm 10.04$ & $77.61 \pm 10.49$ & .063 & .939 \\
\hline \multicolumn{6}{|c|}{$\begin{array}{l}\text { GKEG=Gyrokinesis Exercise Group, EBEG=Elastic Band Exercise Group, } \\
\text { CG=Control Group }\end{array}$} \\
\hline
\end{tabular}


군(Control Group, CG: n=18)으로 분류되었다. 이 연구 는 A대학교 연구윤리심의위원회(IRB;

DKU-2018-11-014)의 승인을 받고 진행하였으며, 이들 연구 대상자들의 신체적 특성은 <Table 1 > 과 같다.

\section{실험처치}

이 연구에서 적용한 두 가지 운동의 형태는 자이로키 네시스 운동 프로그램과 탄성 밴드 운동 프로그램 이며 이들 운동 프로그램은 동일한 장소에서 진행되었다. 두 집단의 운동구성과 시간은 모두 준비운동 10 분, 본 운동 30 분, 정리운동 10 분 총 50 분씩으로 진행하였고, 운동 빈도는 두 집단 모두 주 3 회, 8 주 동안 실시하였다. 운동 강도는 자이로키네시스 운동 프로그램의 경우 운동 속도 (분당 반복횟수 및 동작의 템포)를 달리함으로써 조정하 였고, 탄성 밴드 운동 프로그램은 밴드의 색깔과 운동속 도(분당 반복횟수 및 동작의 템포)를 통해 강도를 조정하 였다. 두 가지 형태의 운동집단 모두 파일럿 검사(Pilot Test, n=4)를 통해 처치 전에 운동 중 심박수준(\%HRR) 과 Borg의 Rating Perceived Exertion(RPE) 수준으로 강도를 점검하였다[23]. 또한 이들 집단의 운동 강도를 준비운동과 정리운동에서는 RPE 9(very light) 11(Fairly) 수준에서 진행되었고, 본 운동에서는 11(Fairly) - 14(Somewhat hard) 수준의 운동 강도를 유지하였다. 한편, 통제군은 특별한 운동을 실시하지 않 고 일상생활을 수행하도록 하였다.

\section{자이로키네시스 운동 프로그램}

자이로키네시스 운동 프로그램은 본래 60 분 혹은 90 분 동안 정해진 연속동작으로 진행되고 있다. 그러나 선행연구 들에서 노인들을 대상으로 한 탄성 밴드 운동프로그램의 운동시간이 50 분인 점을 고려하였고, 이 연구에 참여한 고 령(65-80세)의 피험자들에게 적용 가능한 동작들만을 선 별하여서 50 분 동안의 노인용 자이로키네시스 운동프로그 램을 재구성하였다. 자이로키네시스 운동 프로그램 <Table $2>$ 의 경우, 본 운동은 의자와 마루에서 하는 두 단계로 구 성하였다. 먼저 의자에 앉은 상태에서 자이로토닉 익스펜션 시스템 운동에서 척추 움직임의 기본적 7 가지 방향들을 사 용하는 형태를 기반으로 하여, 척추의 전면과 후면으로 반 원을 만들어 일련의 물결치듯이 움직이게 하는 Arch와 Curling 동작, 척추를 꼿꼿하게 세운 상태에서 좌측과 우측 으로 몸통을 트는 Spiraling Twist 동작, 좌측과 우측 옆으 로 숙여 반원을 만드는 Side Arch 동작, 손가
락 끝에서부터 팔과 어깨에 그 다음 팔을 깍지 끼고 머리 위에서 원을 만들어 주는 것과, 상체를 조수에 밀리는 해 초처럼 옆에서 옆으로 이동하는 것 같은 척추움직임을 회 전형, 나선형의 심화된 동작에서 파생된 다양한 동작들을 수행하게 하였다. 의자 운동을 마치면, 마루에 앉거나 45 도 정도 바닥에 기댄 자세에서 목, 등, 요추, 다리를 연결한 척추 근력 강화 동작(Connecting Series)과 고관절 및 무 릎 가동범위를 증가시키는 동작(Hip-Knee Mobilization), 복근 강화 동작(Abdominal Series)들을 동반된 호흡과 함 께 리드미컬하게 연속적으로 수행하였다.

\section{탄성 밴드 운동 프로그램}

탄성 밴드 운동 프로그램은 고령자의 건강증진 및 근 력 향상을 위하여 적어도 30 분 이상, 주당 3 회 이상 운 동하라는 권고[3]를 기반으로 선행연구들 [24-26]의 운

\begin{tabular}{|c|c|c|c|c|}
\hline Section & Type & $\begin{array}{l}\text { Motion (right, left) \& } \\
\text { Intensity }\end{array}$ & RPE & Time \\
\hline $\begin{array}{l}\text { warm- } \\
\text { up }\end{array}$ & $\begin{array}{l}\text { sitting on } \\
\text { a chair }\end{array}$ & $\begin{array}{l}\text { static stretching, awakening } \\
\text { sense }\end{array}$ & $9-11$ & $10 \mathrm{~min}$ \\
\hline \multirow{20}{*}{$\begin{array}{l}\text { main } \\
\text { exercise }\end{array}$} & \multirow{6}{*}{$\begin{array}{l}\text { sitting on } \\
\text { a chair }\end{array}$} & arch \& curl & & \multirow{6}{*}{$10 \mathrm{~min}$} \\
\hline & & spiraling twist & & \\
\hline & & sideways arches & & \\
\hline & & circles/massaging the organ & & \\
\hline & & wave series & & \\
\hline & & leg/hip series & & \\
\hline & \multirow{3}{*}{$\begin{array}{l}\text { standing } \\
\text { series }\end{array}$} & small knee circles & & \multirow{3}{*}{$5 \mathrm{~min}$} \\
\hline & & ankle circles & & \\
\hline & & kneading of the legs & & \\
\hline & \multirow{6}{*}{$\begin{array}{l}\text { sitting on } \\
\text { a mat }\end{array}$} & curl back in to spiraling twist & & \multirow{6}{*}{$10 \mathrm{~min}$} \\
\hline & & alternating leg series & $11-14$ & \\
\hline & & scooping wave series & & \\
\hline & & pulsation series & & \\
\hline & & $\begin{array}{l}\text { hip knee joint mobilization } \\
\text { series }\end{array}$ & & \\
\hline & & abdominal series & & \\
\hline & \multirow{5}{*}{ standing } & slow walking & & \multirow{5}{*}{$5 \mathrm{~min}$} \\
\hline & & side to side steps & & \\
\hline & & slow turn(right, left) & & \\
\hline & & release kicks & & \\
\hline & & slow turn(left, right) & & \\
\hline $\begin{array}{l}\text { cool- } \\
\text { down }\end{array}$ & $\begin{array}{l}\text { sitting on } \\
\text { a mat }\end{array}$ & dynamic stretching, breathing & $11-9$ & $10 \mathrm{~min}$ \\
\hline Total & & & & $50 \mathrm{~min}$ \\
\hline
\end{tabular}


동 프로그램을 참조하여 이 연구에 적용할 탄성 밴드 운 동 프로그램을 재구성 하되, 가능한 자이로키네시스 운 동 프로그램 동작과 유사한 동작들로 구성하였다. 탄성 밴드 운동 프로그램 <Table 3〉 은 총 50분 동안 준비 운동, 본 운동, 정리 운동 순으로 의자에 앉아서, 마루에 앉아서, 일어서서 수행하는 동작들로 구성하였고, 신체 한 부위를 움직이는 단순동작에서부터 여러 부위가 함 께 움직이는 복합 동작들로 수행 하였다. 본 운동은 의 자에 앉아 탄성 밴드를 사용하여 상체운동(상완의 굴곡 및 신전, 견관절의 관절 가동력, 흉부, 등배, 복부운동) 과 하체운동(슬관절의 굴곡 및 신전, 족관절의 굴곡 및 신전, 고관절 외전 및 내전), 상체와 하체를 동시에 수행 하는 복합운동 형태로 수행 하였다. 정리운동은 두 그룹

\begin{tabular}{|c|c|c|c|c|}
\hline Section & Type & $\begin{array}{c}\text { Motion(right, left) \& } \\
\text { Intensity Yellow(1-5wk) } \rightarrow \\
\text { Red(6-8wk) }\end{array}$ & RPE & Time \\
\hline $\begin{array}{l}\text { warm- } \\
\text { up }\end{array}$ & $\begin{array}{l}\text { sitting on } \\
\text { a chair }\end{array}$ & $\begin{array}{l}\text { static stretching: neck, arm, } \\
\text { chest, pelvis, leg }\end{array}$ & $9-11$ & $10 \mathrm{~min}$ \\
\hline \multirow{18}{*}{$\begin{array}{l}\text { main } \\
\text { exercise }\end{array}$} & \multirow{10}{*}{$\begin{array}{l}\text { sitting on } \\
\text { a chair }\end{array}$} & elbow flexion & \multirow{18}{*}{$11-14$} & \multirow{10}{*}{$15 \mathrm{~min}$} \\
\hline & & shoulder flexion to $90^{\circ}$ & & \\
\hline & & shoulder extension to $180^{\circ}$ & & \\
\hline & & shoulder abduction to $90^{\circ}$ & & \\
\hline & & chest press & & \\
\hline & & rotation with arm extended & & \\
\hline & & single ankle plantar, flexion & & \\
\hline & & single leg extension, flexion & & \\
\hline & & $\begin{array}{l}\text { single leg raise with knee } \\
\text { extended }\end{array}$ & & \\
\hline & & $\begin{array}{l}\text { single leg side kick with knee } \\
\text { extended }\end{array}$ & & \\
\hline & \multirow{5}{*}{$\begin{array}{l}\text { sitting on } \\
\text { a mat }\end{array}$} & abdominal & & \multirow{5}{*}{$10 \mathrm{~min}$} \\
\hline & & chest forward with knee bend & & \\
\hline & & $\begin{array}{l}\text { long-sitting ankle plantar } \\
\text { flexion }\end{array}$ & & \\
\hline & & $\begin{array}{l}\text { single leg raise with knee } \\
\text { extended }\end{array}$ & & \\
\hline & & double leg extension/ flexion & & \\
\hline & \multirow{3}{*}{$\begin{array}{l}\text { standing } \\
\text { back a } \\
\text { chair }\end{array}$} & double ankle raise & & \multirow{3}{*}{$5 \mathrm{~min}$} \\
\hline & & $\begin{array}{l}\text { side hip adduction with knee } \\
\text { extended }\end{array}$ & & \\
\hline & & back hip with knee extended & & \\
\hline $\begin{array}{l}\text { cool- } \\
\text { down }\end{array}$ & $\begin{array}{l}\text { sitting on } \\
\text { a mat }\end{array}$ & dynamic stretching, breathing & $11-9$ & $10 \mathrm{~min}$ \\
\hline Total & & & & $50 \mathrm{~min}$ \\
\hline
\end{tabular}

모두 마루 위에 일어서서 척추의 근육을 머리 중심부(정 수)까지 길게 힘을 주어 신장시킨 상태에서 천천히 제자 리 걷기 후 한 발을 $90^{\circ}$ 도로 들어 올려 몇 초간 동안 중 심을 잡는 등의 운동으로 마무리 하였다.

\section{체력검사}

체력검사는 Rikli와 Jones[27, 28]의 노인체력검사 (Senior Fitness Test)항목으로 상체근지구력(30초간 덤벨 들어 올리기), 하체근지구력(30초간 의자에 앉았 다 일어서기), 하체유연성(의자에 앉아 상체 앞으로 굽 히기), 동적평형성 $(244 \mathrm{~cm}$ 왕복걷기), 전신지구력(2분 동안 제자리걷기) 등이었다. 이들 요소의 체력을 검사 하기 위한 측정방법은 다음과 같다.

상체근지구력검사는 앉아서 30초간 덤벨 들어 올리 기 항목으로 팔걸이가 없는 등받이 의자에 허리를 펴고 앉아 덤벨 $2 \mathrm{~kg}$ (여성)을 들고 바닥과 수직으로 내려놓은 상태에서 시작 신호와 함께 이두근(biceps)을 굽폈다 펴 기를 반복하여 총 횟수를 기록하였다.

하체근지구력검사는 의자에서 30 초간 앉았다 일어 나기 항목으로 등받이 의자에 허리를 펴고 앉아 양팔을 가슴에 교차한 상태에서 시작 신호와 함께 완전히 일어 섰다가 의자에 다시 앉기를 반복하여 일어선 총 횟수를 기록하였다.

하체유연성검사는 의자에 앉아 상체앞으로굽히기 항 목으로 등받이가 있는 의자에 앞쪽 끝부분에 닿도록 걸 쳐 앉아 측정 측 다리의 무를을 곧게 펴 발꿈치가 바닥 에 닿은 상태에서 양손을 모아 허리를 구부며 손을 뻗 어 중지 편 후 발가락 쪽으로 천천히 뻗어 2 초간 유지하 여 발끝과 중지사이의 거리를 $\mathrm{cm}$ 단위로 기록하였다.

동적평형성검사는 등받이가 있는 의자에 앉은 상태 에서 시작 신호와 함께 일어서 출발하여 $244 \mathrm{~cm}$ 에 세 워져 있는 반환점을 돌아 원상태로 돌아와 출발 의자에 앉는데 소요되는 시간을 $1 / 100$ 초 단위로 기록하였다.

전신지구력검사는 편안한 상태에 서서 시작 신호 와 함께 양쪽 무릎 높이를 각각 슬개골(patella)과 장골 (iliac)의 중간 지점까지 올리면서 제자리 걷기를 2 분 동 안 수행 한 총 횟수를 기록하였다.

\section{자료처리방법}

이 연구의 자료처리는 SPSS 25.0 version 통계 프 로그램으로 통계처리 하였다. 각 집단의 모든 종속 변인 별 평균과 표준편차를 산출하였다. 각 변인의 사전검사 
에 대한 집단 간 차이를 확인하기 위하여 일원배치 분산 분석을 통해 동질성 검사를 수행하였다. 또한 세 운동집 단과 운동프로그램 참여 이전과 이후에 따른 종속변인 들의 평균차를 검증하기 위해 $3 \times 2$ 일원배치 분산분석 (one-way ANOVA with repeated measures)과 집단간 의 사후검증(post-HOC)을 위해 Scheffe 방법을 적용하 여 분석하였다. 통계적 유의수준은 $a=.05$ 로 설정하였다.

\section{결과}

이 연구의 실험결과는 <Table 4 >과 같다.

상체근지구력을 평가하기 위하여 실시한 '30초간덤 벨들어올리기' 성적에 대한 반복측정 변량분석 결과, 집 단 간 주 효과는 통계적으로 유의한 차이가 나타나지 않 았으나 $(\mathrm{p}=.141)$, 운동 전·후 사이의 주 효과는 통계적으 로 유의한 차이가 나타났으며 $(\mathrm{p}=.000)$, 운동집단과 측 정시기 간의 상호작용 효과도 유의한 것으로 나타났다 $(\mathrm{p}=.009)$. 집단 간 사후검사 결과에 대한 일원배치 분 산분석을 실시하고 Scheffe 방법의 사후검증을 실시한
결과, 집단 간 차이가 없었다.

하체근지구력을 평가하기 위해 실시한'30초간의자 에앉았다일어서기' 성적에 대한 반복측정 변량분석 결 과, 집단 간 주 효과 $(\mathrm{p}=.013)$ 및 사전·사후 검사 간 주 효과 $(\mathrm{p}=.000)$ 뿐만 아니라 운동집단과 측정시기 간에 상호작용 효과가 유의하게 나타났다 $(\mathrm{p}=.000)$. 집단 간 사후검사 성적에 대한 일원배치 분산분석 및 다중비교 의 Scheffe 방법에 의한 사후검증을 실시한 결과 두 개 의 운동집단(GKEG, $\mathrm{EBEG})$ 과 통제집단 $(\mathrm{CG})$ 사이에는 통계적으로 유의한 차이가 나타났으나 $(\mathrm{p}=.000)$ 운동집 단 간 차이는 없었다.

하체유연성을 평가하기 위해 실시한'의자에앉아상 체앞으로굽히기'검사 성적에 대한 반복측정 변량분석 결과, 집단 간 주 효과 $(\mathrm{p}=.002)$ 및 사전·사후 간 주 효 과 $(\mathrm{p}=.003)$, 그리고 운동집단과 측정시기 간에 상호작 용 효과 $(\mathrm{p}=.000)$ 모두 유의하게 나타났다. 집단 간 사 후검사 성적에 대한 일원배치 분산분석 및 다중비교의 Scheffe 방법에 의한 사후검증을 실시한 결과, 두 개의 운동집단(GKEG, $\mathrm{EBEG})$ 과 통제집단 간에는 통계적으

Table 4. Results of Physical Fitness $(M \pm S D)$

\begin{tabular}{|c|c|c|c|c|c|c|c|}
\hline Variables & Tests & GKEG(1) & EBEG(2) & CG(3) & Source & $\boldsymbol{F}$ & post-HOC \\
\hline \multirow{4}{*}{$\begin{array}{l}\text { Upper } \\
\text { Muscular Endurance } \\
\text { (30-Second Arm Curl: sec) }\end{array}$} & Pre-test & $15.00 \pm 4.81$ & $11.15 \pm 4.36$ & $15.55 \pm 6.81$ & A & 2.033 & \multirow{4}{*}{ NS } \\
\hline & & & & & & & \\
\hline & Post-test & $21.73 \pm 3.88$ & $19.70 \pm 6.09$ & $19.72 \pm 4.63$ & B & $136.398^{* *}$ & \\
\hline & & & & & $A \times B$ & $5.214^{*}$ & \\
\hline \multirow{3}{*}{$\begin{array}{l}\text { Lower } \\
\text { Muscular Endurance } \\
\text { (30-Second Chair Stand: sec) }\end{array}$} & Pre-test & $10.57 \pm 4.59$ & $9.45 \pm 3.03$ & $9.44 \pm 2.63$ & A & $4.753^{*}$ & \multirow{3}{*}{ (1) (2) > (3) } \\
\hline & Post-test & $15.63 \pm 4.78$ & $13.05 \pm 3.79$ & $9.38 \pm 2.89$ & $B$ & $174.373^{* *}$ & \\
\hline & & & & & $A \times B$ & $47.589^{* *}$ & \\
\hline \multirow{3}{*}{$\begin{array}{l}\text { Lower Flexibility } \\
\text { (Chair Sit \& Reach: cm) }\end{array}$} & Pre-test & $1.02 \pm 2.99$ & $-2.59 \pm 6.55$ & $-1.51 \pm 7.28$ & $A$ & $6.743^{* *}$ & \multirow{3}{*}{ (1) (2) $>$ (3) } \\
\hline & Post-test & $6.50 \pm 3.05$ & $2.18 \pm 3.07$ & $-4.22 \pm 11.05$ & B & $9.801^{* *}$ & \\
\hline & & & & & $A \times B$ & $10.321^{* *}$ & \\
\hline \multirow{3}{*}{$\begin{array}{l}\text { Dynamic Balance } \\
\text { (8-Fit Up \& Go: sec) }\end{array}$} & Pre-test & $14.98 \pm 4.86$ & $16.86 \pm 3.93$ & $14.07 \pm 4.47$ & A & .925 & \multirow{3}{*}{ NS } \\
\hline & Post-test & $12.38 \pm 3.57$ & $13.57 \pm 2.96$ & $13.45 \pm 4.48$ & $B$ & $64.739^{* *}$ & \\
\hline & & & & & $A \times B$ & $8.664^{* *}$ & \\
\hline \multirow{4}{*}{$\begin{array}{l}\text { Endurance } \\
\text { (2-Min Walk: number) }\end{array}$} & Pre-test & $61.21 \pm 18.12$ & $69.05 \pm 12.97$ & $75.44 \pm 21.34$ & $A$ & .611 & \multirow{4}{*}{ (1) (2) $>$ (3) } \\
\hline & & & & & & & \\
\hline & Post-test & $88.57 \pm 11.02$ & $91.00 \pm 13.40$ & $75.44 \pm 23.79$ & $B$ & $88.488^{* *}$ & \\
\hline & & & & & $A \times B$ & $22.251^{* *}$ & \\
\hline
\end{tabular}

Values are means \pm SD. GKEG(1): Gyrokinesis Group(n=19), EBEG(2): Elastic Band Group(n=20), CG(3): Control Group( $n=18)$, A: Group, B: Measurement, A $\times \mathrm{B}$ : Interaction, ${ }^{*} p<.05,{ }^{* *} p<.01$, NS: No Significant 
로 유의한 차이가 나타났으나 $(\mathrm{p}=.002)$ 운동집단 간 차 이는 없었다.

동적평형성을 평가하기 위해 실시한‘ $244 \mathrm{~cm}$ 왕복걷 기'성적에 대한 반복측정 변량분석 결과, 집단 간 주 효 과 $(\mathrm{p}=.403)$ 는 통계적으로 유의한 차이가 나타나지 않았 지만, 사전·사후 간 주 효과 $(\mathrm{p}=.000)$ 는 통계적으로 유의 한 차이가 나타났으며 운동집단과 측정시기 간에 유의 한 상호작용 효과 $(\mathrm{p}=.001)$ 가 나타났다. 집단 간 사후검 사 결과에 대한 일원배치 분산분석을 실시하고 Scheffe 방법의 사후검증을 실시한 결과, 집단 간 차이가 없었다.

전신지구력을 평가하기 위해 실시한' 2 분동안제자리 걷기'검사성적에 대한 반복측정 변량분석 결과, 운동 후 집단 간 주 효과 $(\mathrm{p}=.547)$ 는 통계적으로 유의한 차이 가 나타나지 않았다. 그러나 사전·사후 검사 간 주 효과 $(\mathrm{p}=.000)$ 는 통계적으로 유의한 차이가 나타났으며, 운 동집단과 측정시기 간에 상호작용 효과 $(\mathrm{p}=.000)$ 도 유의 하게 나타났다. 집단 간 사후검사 성적에 대한 일원배치 분산분석 및 다중비교의 Scheffe 방법에 의한 사후검증 을 실시한 결과, 두 개의 운동집단(GKEG, $\mathrm{EBEG}$ )과 통 제집단 간에는 통계적으로 유의한 차이가 나타났으나 $(\mathrm{p}=.003)$ 운동집단 간에는 차이는 없었다.

결과적으로, 모든 변인에서 집단 및 측정시기 사이의 상호작용 효과가 유의하게 나타남으로써 자이로키네시 스 운동과 탄성밴드 운동은 운동을 하지 않은 통제집단 에 비해 노인체력을 유의하게 향상시키는 것으로 나타 났다. 그러나 Scheffe 방법을 통한 사후 검증 결과를 살 펴볼 때, 상체근지구력(30초간덤벨들어올리기)와 동적 평형성 $(244 \mathrm{~cm}$ 왕복걷기)에서는 집단 간 차이가 없었고, 하체근지구력(30초간의자에앉았다일어서기)와 하체유 연성(의자에앉아상체앞으로굽히기), 전신지구력(2분동 안제자리걷기) 등에서는 통제집단 보다 운동집단들이 더 높은 값을 나타냈지만 자이로키네시스 운동집단과 탄성 밴드 운동집단 간의 차이는 찾아볼 수 없었다.

\section{논의}

이 연구는 8 주 동안의 자이로키네시스 운동과 탄성 밴드 운동이 노인 여성의 체력에 미치는 효과를 비교하 고자 하는 연구였다. 연구 결과, 자이로키네시스 운동 및 탄성 밴드 운동 프로그램 모두가 하체근지구력, 하체유연 성, 동적 평형성, 전신지구력 등 다양한 요소의 노인 체력
을 개선시키는 효과를 나타냈지만 두 가지 운동 프로그램 사이에 효과의 차이는 나타나지 않았다.

선행 연구들에서 운동 유형에 따른 노인들에서도 체 력의 운동효과가 다양하게 나타나고 있음이 증명되고 있다. Liu \& Latham[29]과 LaStayo, et al.[30]은 유 산소 운동과 저항성 운동에서 노년기에 중요시 되는 근 력, 보행속도, 유연성, 평형성 및 민첩성 등의 증진에 효과가 있다고 하였다. Kwon \& Kim[31]은 수영과 게이트볼 운동에 참여한 여성 노인들의 배근력, 악력, 윗몸앞으로굽히기 및 전신반응 등이 개선되었다고 했 으며, Misic, et al.[32]은 규칙적인 신체활동은 노인 의 심폐기능, 근력, 유연성 등을 향상된다고 하였다.

여성 노인을 대상으로 탄성 밴드 운동프로그램을 적 용한 선행연구들에서도 여러 가지 체력 요소들의 개선 이 발견되었다. Lee[33]는 8주간 노인 20명을 대상으 로 탄성 밴드 운동 프로그램을 적용한 결과 근력, 평형 성, 고유수용성감각의 증가를 보고하였고, $\mathrm{Kim}[34]$ 은 허약 노인 12 주간 주 3 회 탄성밴드 운동을 실시한 결과 악력, 팔구부리고펴기, 엎드려상체들기 등의 성적이 유 의하게 증가함을 발견하였다. Lee \& Kim[35]은 노인 여성 22 명에게 탄성 밴드 운동을 12 주간 주 3 회 실시한 후, 상-하지 근력, 유연성, 평형성 등이 증가하였음 보 고하였다. 그리고 Taaffe[36]는 근육감소의 예방을 위 한 운동요법으로 탄성 밴드 운동이 직접적인 역할을 한 다고 보고 하였다. Ahn[21]은 치매 노인을 대상으로 5 개월간 주 3 회 탄성 밴드 운동을 실시한 후, 상지근력이 유의하게 증가함을 보고하였다. Jette \& Assmann[20] 는 215 명의 신체적 장애가 있는 노인들에게 가정에서 탄성 밴드 운동을 6 개월 동안 실시한 결과 하지근육은 $6 \%$ 12\% 증가 되었고, 신체장애는 $15 \%$ 18\% 감소되 었다고 보고하였다. 그리고 Lee[33]는 8주간 노인 20명 을 대상으로 탄성 밴드 운동 프로그램이 노인의 근력, 평 형성, 고유수용성감각에 증가에 효과가 있다고 하였다. 그러나 자이로토닉 익스팬션 시스템이 노인 여성의 체력에 미치는 영향에 관한 연구는 흔치 않다. 자이로 키네시스 운동프로그램을 적용한 연구는 주로 젊은이 들을 대상자로 있지만 그 결과들을 살펴보면, Karen et al.[37]는 자이로키네시스 운동을 통하여 자기규제에 의한 자기효능감의 향상을, Park[14]는 정적 균형이나 보행패턴의 개선을, Kim \& Shim[38]은 심폐지구력과 순발력 그리고 오른쪽 외발서기 등의 향상을 보고하였 
다. 자이로 토닉 운동프로그램을 적용한 연구를 살펴보 면, Kim, et al.[12]과 Kang[39] 의 연구가 있는데 그 들은 자이로토닉 운동이 근력 강화 및 유연성에 도움이 되며, 만성 요통 환자의 요부 신근력, 유연성의 개선이 있었다고 하였다.

이 연구에서 자이로키네시스 운동과 탄성 밴드 운동 모두가 노인 여성의 상체근지구력, 하체근지구력, 하체 유연성, 동적평형성, 전신지구력 등의 요소를 개선시킨 점을 고려할 때 노인을 위한 운동으로 소도구만이 필요 한 매우 간편하고 편리한 운동프로그램으로서 노인여성 들의 체력관리에 널리 사용될 가치가 있다고 사료된다.

한편, 자이로키네시스 운동은 상완의 움직임과 하체 의 지지를 통하여 척추 움직임 주변 근육의 강화를 목적 으로 개발된 운동프로그램이기[39-41] 때문에 탄성 밴 드 운동과는 다른 특이한 효과[42]를 나타나기를 기대 하였으나 두 가지 운동집단 간의 효과의 차이는 발견되 지 않았다. 그러나<Table 4>에서 보듯이 8주간의 훈련 전후 성적에서 두 집단의 기울기에 차이가 있음을 볼 때 훈련 기간을 더 늘려 잡는다면 두 운동 간의 훈련효과의 차이가 나타날 가능성을 배제할 수는 없다고 사료된다.

\section{결론}

8주 동안 자이로키네시스 운동훈련은 상체근지구력, 하체근지구력, 하체유연성, 동적 평형성, 전신지구력 등 다양한 요소의 노인 체력을 향상시키는 것으로 나타났지 만 그 효과가 탄성 밴드 운동 프로그램 실시한 집단과 큰 차이는 없었다. 하지만 척주기능 향상을 목적으로 개발된 자이로키네시스 운동도 탄성밴드 운동과 함께 노인 체력의 유지 및 증진을 위한 운동 프로그램으로 적극 권장될 수 있 다고 판단된다. 아울러 자이로 키네시스 운동의 체력적 특 이성을 밝히기 위해서는 적어도 훈련기간을 12 주 이상 늘 려 잡는 장기간의 실험처치를 통한 후속연구가 요망된다.

\section{References}

1. Statistic Korea. 2017.

2. Koo HM. Proposal of physical activity promotion plan for older adult by domestic policy status. Seoul: Korea Health Promotion Institute. 2017.

3. ACSM. ACSM position stand: exercise and physical activity for older adults. Med Sci Sports Exerc. 2009, p 15101530.

4. Kang SJ. The effect of Sarcopenia index, inflammation cytokine and insulin resistance in aerobic and resistance exercise of frail elderly women. The Korean Journal of Physical Education. 2014; 53(2):497-508.

5. Kong S, Sung SC, Kim HS. Efficacy in methods of Sarcopenia diagnosis index. Kinesiology. 2016, p 15-23.

6. Hong JY. Effects of 12 weeks aerobic.resistance-combined exercise training on physiological and psychological factors in obese elderly women - focused on the Sarcopenia and fall efficacy. Graduate School Dankook University. Cheonan; Korea. 2012.

7. Bang HS. The effects of exercise type performance on Alzheimer`s disease Dementia Factor, and Cognitive Function and Fall related Fitness in elderly women. Korean Journal of Sports Science. 2018; 27(6):12891304.

8. Park HS, Kim HS. The Effects of In-facility Exercise Program on Fall-Related Fitness and Cognitive Function in Elderly with Dementia. J Korean Soc Living Environ Sys. 2010; 17(1):77-85.

9. Hong SY. Effects of an 8-week individualized exercise program on parameters of functional capacity, mobility and cognitive function in elderly persons with Dementia. Journal of the Korean Society of Living Environmental System 2012; 19(3):352-361.

10. Paterson DH, Jones GR, Rice CL. Ageing and physical activity: Evidence to develop exercise recommendations for older adults. Can J Public Health. 2007; S98:69-108

11. U. S. Department of Health and Human Services. Physical Activity Guidelines for Americans. 2008. www.health. gov/paguidelines.

12. Kim HB, Lee HS, Lee WY, et al. Effects of Gyrotonic Expansion System(R) Training and MedX Training on Lumbar Extension Strength, Lumbar Flexibility and Relief of Pain with Chronic Low Back Pain Patients. The Korea of Journal of Sports Medicine, 2009; 27(2):127-136.

13. Kim SJ, Baik YS. Effects of Gyrotonic exercise program on Cobb's angle of patients with idiopathic scoliosis. 
Korean Journal of Exercise Rehabilitation. 2012; 8(3):239-248.

14. Park SY. Effects of Gyrotonic exercise on sagittal spinal alignment, static balance, gait pattern and pain-scale of female office workers. Pusan National University, Pusan, Korea. 2015.

15. Gyrotonic Association of Seoul. http://gyrotonicseoul. co.kr/. (Accessed January 1, 2019).

16. Petterson M, Stegink W, Hgan A, Nassif K. Effect of 14weeks of resistance training on lipid profile and body fat percentage in premenopausal woman. Br J Sports Med. 2001; 33(3):190-195.

17. Hughes CJ, Hurd K, Jones A, Sprigle S. Resistance properties of Thera-Band tubing during shoulder abduction exercise. J Orthop Sports Phys Ther. 1999; 29(7):413-420.

18. Park HS, Yoon BC. The effects of on resistive exercise of lower limb 's used Thera-Band on factors related to falls in elderly woman. Journal of Sport and Leisure Studies. 2009, 73-779.

19. Page PA, Labbe, Topp R. Clinical Force Production, of Thera-Band Elastic Bands. J Orthop Sports Phys Ther. 2000; 30(1):47-48.

20. Jette AM. Krebs DE, Assmann SF. Related Articles, Links Moderate exercise improves gait stability in disabled elders. Arch Phys Med Rehabil. 1998; 79(12):1489-95.

21. Ahn NY. Effects of an elastic band resistance exercise program on upper extremity muscle strength in patients with Dementia. Journal of Coaching Development. 2015; 17(2):91-98.

22. Kang SJ. The Effect of Sarcopenia Index, Inflammation Cytokine and Insulin Resistance in Aerobic and Resistance Exercise of Frail Elderly Women. The Korean Journal of Physical Education. 2014; 53(2):497-508.

23. ACSM. ACSM's guidelines for exercise testing and prescription. Mc Baltimore. Williams \& Wilkins, USA. 2006; 5:443-444.

24. Kim DJ, Kim JH. The effects of weight training and elastic band for the elderly. Korean Journal of Sports Science. 2010; 19(3):1103-1115.

25. Kim JH, Cho EH, Jun TW, Shin HS. The Effects of Long- term Combined Exercise on Body Composition, Health-related Fitness and Blood Lipids of Elderly Women. Journal of Korean Association of Physical Education and Sport for Girls and Women. 2015; 29(3):235-248.

26. Han KH, Bae KH. The Effect of Different Exercise-based Interventions on Senior Fitness Test of Elderly. The Korean Journal of Physical Education. 2018; 57(2):635646.

27. Rikli E, Jones J. Senior fitness test. Champaign (IL). Human Kinetics. USA. 2001.

28. Kim HS, Park WY. Senior fitness test Manual. Deahanmedia. Korea. 2014

29. Liu CJ, Latham NK. Progressive resistance strength training for improving physical function in older adults. Cochrance Database System Review. 2003, CD002759.

30. LaStayo PC, Ewy GA, Pierotti DD, Johns RK, Lindstedt S. The positive effects of negative work: Increased muscle strength and decreased fall risk in a frail elderly population. J Gerontol A Biol Sci Med Sci. 2003; 58(5):419-424.

31. Kwon JJ K, Kim KJ. ADL, IADL and fitness in the female olders participating swimming and gate ball. The Korean Journal of Growth and Development. 2003; 11(2):1-11.

32. Misic MM, Valentine RJ, Rosengren KS, Woods JA, Evans EM. Impact of training modality on strength and physical function in older adults. Gerontology. 2009; 55(4):411-6.

33. Lee DJ. Effects of Theraband exercise programs on strength, balance and proprioception in elderly. Journal of the Korean Society of Integrative Medicine. 2014; 2(4):1-8.

34. Kim SM. Effect of elastic band based resistance exercise on upper limbs strength and ADL of frail elders. The Korean Journal of Health Service Management. 2012; 6(2):71-80.

35. Lee HB, Kim TS. The effects of elastic band training on functional fitness and aging-related hormones in aged women. Journal of the Korean Society for Wellness. 2018; 13(3):629-637.

36. Taaffe R. Sarcopenia: Exercise as a treatment strategy. Australian Family Physician. 2006; 35(3):130-133. 
37. Karen C, Mandy H, Marianne A, et al. Developing mindfulness in college students through movement based courses: effects on self-regulatory self-efficacy, mood, stress, and sleep quality. J Am Coll Health. 2010; 58(5):433-442.

38. Kim JH, Shim SM. The effects of Gyrokinesis and Pilates exercises for 10 weeks on the body composition and physical fitness of female college students majored in model. Journal of the Korean society for Wellness. 2018; 13(2):475-485.

39. Kang MH. The effects the Gyrotonic expansion system and lumbar stabilization exercise on the lumbar isometric extension strength and pain relife of middle aged women with low back pain patients. The Korea Journal of Sports Science. 2012; 21(3):829-839.
40. Yoon SH. A Clinical Study of Gyrotonic Expansion System Program for the Treatment of Scoliosis. J Phy Grow Mot Dev, 2003; 11(3):149-155.

41. Kim SJ, Baik YS. Effects of Gyrotonic Exercise Program on Cobb's Angle of Patients with Ldiopathic Scoliosis. Korean Journal of Exercise Rehabilitation. 2012; 8(3):239-248.

42. Kim YL, Kwak YS. Effects of Different Exercise Training Mode on Exercise Specificity and Transability. Journal of Life Science. 2009; 19(7):968-975.

43. Kim YL, Kwak YS. Effects of Different Exercise Training Mode on Exercise Specificity and Transability. Journal of Life Science. 2009; 19(7):968-975. 